\title{
Posisi dan Pencapaian Wisran Hadi dalam Arena Sastra Indonesia
}

\section{Position and Achievements of Wisran Hadi in the Indonesian Literature Arena}

\author{
Lastry Monika ${ }^{a}$ \\ aUniversitas Gadjah Mada \\ Pos-el: lastry.monika@yahoo.com
}

\begin{abstract}
Abstrak
Wisran Hadi dikenal sebagai sastrawan dan budayawan Indonesia yang telah menghasilkan karya-karya dalam beragam genre. Selama kariernya, karya-karya yang ia hasilkan tidak hanya memperoleh sejumlah penghargaan, tetapi juga menimbulkan kontroversi dari kelompok masyarakatnya sendiri, yaitu Minangkabau. Terkait hal itu, maka penelitian mencoba mengkaji posisi dan pencapaian Wisran Hadi dalam arena sastra Indonesia. Pembahasan meliputi upaya yang dilakukan pengarang mencapai posisi, beroperasi dalam arena sastra, dan dalam mempertahankan posisi. Berdasarkan teori strukturalisme genetik Pierre Bourdieu, hasil analisis menunjukkan sebagai berikut. Pertama, posisi arena sastra yang ditempati oleh Wisran Hadi dominan menempati prinsip hierarki otonom sehingga cenderung berseberangan dengan hukum yang berlaku dalam arena kekuasaan. Struktur arena sastra yang ditempati ialah arena produksi terbatas. Kedua, pencapaian posisi didasarkan pada habitus, praktik berkesenian, perolehan serta pertukaran modal simbolis, perolehan penghargaan, serta kebertahanan kelompok Bumi Teater. Ketiga, praktik dan strategi dalam mempertahankan posisi ialah dengan menghasilkan karya dalam beragam genre, mengedepankan ekplorasi kata dan bahasa, serta mengelaborasi karya klasik seperti kaba, tambo, dan sejarah. Selain itu, karya disituasikan berdasarkan beragam unsur seperti habitus, struktur arena yang ditempati, posisi dalam arena, hingga situasi dan kondisi realitas sosial yang menjadi sumber serta sasaran dari karya.
\end{abstract}

Kata-kata kunci: arena sastra, posisi, habitus, praktik, strategi, Wisran Hadi, Bourdieu

\begin{abstract}
Wisran Hadi is known as a man of letters and an expert in culture who has produced works in various genres. During his career, the works he produced not only received a number of awards, but also caused controversy from his own community group in the Minangkabau. In this regard, this research tries to examine the position and achievements of Wisran Hadi in the arena of Indonesian literature. The discussion includes the efforts made by the author to achieve a position, to operate in the literary arena, and to maintain his position. Based on Pierre Bourdieu's theory of genetic structuralism, the results of the analysis show the following. First, the position of the literary arena occupied by Wisran Hadi is dominantly on the principle of an autonomous hierarchy, so that it tends to contradict the laws that apply in the arena of power The structure of the literary arena is a limited production arena. Second, the achievement of positions based on habitus, artistic practice, the acquisition and exchange of symbolic capital, the acquisition of awards, and the survival of the Bumi Teater group. Third, practices and strategies in maintaining position are by producing works in various genres, prioritizing exploration of words and languages, and elaborating classic works such as kaba, tambo, and history. In addition, the work is positioned based on various elements such as habitus, the structure of the arena occupied, the position in the arena, to the situation and conditions of social reality that are the source and target of the work.
\end{abstract}

Keywords: literary arena, position, habitus, practice, strategy 


\section{PENDAHULUAN}

Karya sastra tidak hadir begitu saja ke hadapan pembaca. Misalnya, suatu karya hadir dan membawa pengaruh dari bagaimana latar belakang pengarang yang membuat karya tersebut. Selain itu, karya sastra juga dipengaruhi oleh situasi penciptaan karya yang ada. Pengarang misalnya, melewati beragam proses dalam memproduksi karyanya hingga ia menempati posisi tertentu dalam arena sastra.

Berdasarkan pernyataan tersebut, maka dapat dinyatakan bahwa arena sastra berhubungan dengan aktivitas serta berperan dalam proses kepengarangan, dan begitu pula sebaliknya. Latar belakang pengarang, serta lingkungan yang ia tempati memiliki peran dan pengaruh yang penting dalam penciptaan karya-karyanya. Oleh sebab itu, memahami karya sastra tidak cukup hanya dari apa yang dinarasikan oleh teks. Akan tetapi, perlu pula untuk memahami bagaimana, di mana, mengapa, dan dari siapa karya itu dihadirkan.

Jawaban dari pertanyaanpertanyaan tersebut, erat kaitannya dengan apa yang disebut sebagai arena sastra. Bahasan mengenai arena sastra menjadi salah satu bahasan dari perspektif tentang sosiologi sastra yang dikemukakan oleh Pierre Felix Bourdieu. Ia mengemukakan bahwa membahas arena sastra berarti sama halnya dengan mengamati karya sastra yang diproduksi oleh semesta sosial tertentu yang memiliki institusi-institusi tertentu, serta mematuhi hukum-hukum tertentu (Bourdieu, 2010).

Salah satu wilayah di Indonesia yang cukup terkenal dengan pengarangpengarang yang cukup terkemuka pada zamannya ialah Sumatra Barat. Beberapa nama pengarang tersebut di antaranya ialah Marah Rusli, Abdoel Moeis, A. A. Navis, Nur Sutan Iskandar, Taufiq Ismail, Hamka, Darman Moenir, Rusli Marzuki Saria, Wisran Hadi, Leon Agusta, dan sebagainya. Beberapa di antara pengarang tersebut cukup ramai dibicarakan pada masanya. Misalnya A. A. Navis melalui cerpen "Robohnya Surau Kami" menjadi perbincangan pada tahun 1955. Sapardi menyebut bahwa Navis memberi warna baru bagi dunia sastra Indonesia (A.A. Navis, 2018). Cerpen tersebut menjadi kontroversi dan mengejutkan pembaca karena menarasikan cerita sindiran terkait kehidupan beragama. Akan tetapi, cerpen itulah yang justru turut menegaskan posisi A. A. Navis dalam arena sastra Indonesia.

Pada perkembangannya, para kritikus di Sumatra Barat menganggap tidak ada lagi karya-karya bermutu seperti demikian yang muncul dari pengarangpengarang muda. Pernyataan tersebut salah satunya dinyatakan oleh Darman Moenir pada tahun 2011. Ia menyatakan bahwa sejak 30 tahun terakhir tidak ada novel bermutu dari Sumatra Barat hingga muncul novel Persiden karya Wisran Hadi yang dianggap membawa warna baru (Zarman, 2014). Akan tetapi, klaim seperti demikian ditentang oleh para pengarangpengarang muda. Pernyataan tersebut dianggap sebagai gambaran dampak dari standarisasi Orde Baru yang sentralis termasuk dalam hal kesusastraan. Namun, di sisi lain, karya-karya Wisran Hadi memang sering menimbulkan kontroversi, terutama dalam naskah drama yang ia tulis. Birowo menyebut Wisran Hadi adalah salah satu sastrwan yang mewakili agen dominan dari dekade 1970-an hingga 
1990-an di arena kesusastraan Sumatra Barat (Birowo, 2014). Anggapan tersebut didasarkan pada legitimasi atas naskahnaskah drama yang ditulis, hingga penyutradaraan-penyutradaraan yang ia garap.

Wisran Hadi tidak hanya berkarya dalam satu bidang kesenian, atau menulis karya sastra dalam satu genre saja. Karya satra yang paling banyak ia tulis dalam kepengarangannya ialah naskah drama. Oleh sebab itu, ia juga dikenal sebagai seorang dramawan. Akan tetapi, Wisran Hadi juga menulis jenis karya sastra lain seperti cerita pendek dan novel. Berdasarkan hal itulah ia juga dikenal sebagai cerpenis dan novelis.

Hingga saat ini, telah banyak dari karya-karya Wisran Hadi tersebut diteliti dari berbagai perspektif. Hal yang dominan dibahas pada umumnya ialah mengenai kebudayaan dan adat Minangkabau yang ditampilkan. Misalnya, penelitian dengan judul "Mencermati Perubahan Sosial Masyarakat Minangkabau Melalui Novel Tamu Karya Wisran Hadi" (Fatimah, 2008). Penelitian tersebut memaparkan tentang pergeseran sistem nilai di Minangkabau, salah satunya dikarenakan kebijakan rezim Orde Baru yang sentralistis dan otoriter. Masyarakat tidak memiliki pilihan atas aturan-aturan yang ditetapkan. Sebagai bentuk penyesuaian, misalnya, pandangan masyarakat terhadap tanah ulayat bergeser dan menyebabkan persilihan antaranggota kaum. Dalam hal ini, novel Tamu dianggap sebagai gagasan dan perasaan Wisran Hadi yang mewakili kelompok sosialnya.

Penelitian lain ialah "Representasi Identitas dan Etnisitas Minang dalam
Novel Persiden Karya Wisran Hadi" (Sugiarti, 2013). Melalui penelitiannya, Sugiarti mengemukakan bahwa identitas dan etnisitas rumah Bagonjong menghadapi sejumlah persoalan yang tidak menemukan solusi dikarenakan semua tokoh memiliki perbedaan pendapat. Cara pandang mengenai persoalan adat tersebut disebut sebagai upaya Wisran Hadi dalam mengomunikasikannya melalui novel.

Kedua hasil penelitian tersebut memiliki kecenderungan mengkaji karya sastra secara tekstual, kemudian dikaitkan dengan kontekstualnya. Pada umumnya terkait dengan kebudayaan dan masyarakat. Hal tersebut belum terlalu bersinggungan dengan arena sastra yang mencakup tempat atau proses kehadiran karya sastra, serta bagaimana dan mengapa karya itu diciptakan oleh pengarang. Terkait hal ini, Bourdieu mengatakan bahwa eksistensi arena sastra, praktik-praktiknya, dan karya sastra merupakan hal yang tidak terpisahkan dari eksistensi pengarang (Bourdieu, 2010).

Sejauh pengamatan, hingga saat ini belum begitu banyak yang mencoba menelusuri posisi Wisran Hadi dalam arena sastra. Akan tetapi, berhubungan dengan biografi pengarang, terdapat penelitian dengan judul "Wisran Hadi: Biografi Seorang Sastrawan 1972-2010" (Sofia, 2010). Pada penelitian tersebut dipaparkan bahwa Wisran Hadi merupakan sastrawan yang dikenal sejak 1970-an. Ia menulis berbagai macam karya sastra dan dominan dilatarbelakangi oleh budaya dan sejarah Minangkabau. Penelitian tersebut secara keseluruhan lebih bersifat deskriptif dengan memaparkan biografi dari Wisran Hadi. 
Untuk memahami praktik-praktik pengarang, tidak hanya cukup dengan memahami karya-karyanya. Oleh sebab itu, perlu pula untuk dipahami antara sejarah posisi-posisi yang mereka tempati dengan sejarah disposisi mereka dalam arena yang ditempati. Secara lebih rinci, perlu untuk dipahami bagaimana pengarang menempati atau mencapai posisi dalam arena sastra? Kemudian, bagaimana pengarang beroperasi dalam arena yang ditempati serta upaya dalam mempertahankan posisinya? Berdasarkan hal itu, maka penelitian ini menjadikan Wisran Hadi dalam arena sastra sebagai objek material. Selain itu, posisi serta strateginya dalam arena sastra dielaborasi berdasarkan perspektif strukturalisme genetik Pierre Bourdieu sebagai objek formal. Perspektif tersebut digunakan untuk menjawab pertanyaan-pertanyaan yang telah dipaparkan sebelumnya.

\section{LANDASAN TEORI}

Bourdieu mengemukakan dua konsep penting dalam teorinya. Konsep tersebut ialah habitus dan arena. Bourdieu menyatakan bahwa habitus dihadirkan untuk menengahi dualisme antara pelaku dan struktur (Bourdieu, 2010). Secara ringkas, Bourdieu menyebut habitus sebagai struktur sosial yang dibatinkan, lalu kemudian diwujudkan (Bourdieu, 1990). Lebih lanjut, ia memaparkan bahwa habitus diawali dari pertanyaan yang berhubungan dengan bagaimana perilaku dapat diatur tanpa adanya keharusan ketaatan terhadap aturan.

Kemudian, konsep mengenai arena yang dalam penelitian ini mengacu pada arena sastra didefinisikan oleh Bourdieu sebagai sebuah semesta sosial independen, di dalamnya terdapat hukum-hukum tersendiri yang terkait dengan keberfungsian anggotanya (Bourdieu, 2010: 215). Selain itu, di dalam arena tersebut juga terdapat hubungan kekuasaan mencakup yang mendominasi dan yang didominasi. Berhubungan dengan pernyataan tersebut, Bourdieu juga menjelaskan bahwa melalui habitus diperoleh struktur yang jelas (Bourdieu, 2011). Dengan kata lain, sebuah dunia sosial dalam arena sastra yang telah terbukti dengan sendirinya sejak dahulu.

Di dalam arena sastra terjadi pergulatan dalam memperebutkan posisi serta disposisi tertentu. Selain perebutan posisi, arena sastra juga melibatkan kekuasaan dalam memublikasikan atau menolak publikasi. Bourdieu juga memperkenalkan modal simbolis serta pertukaran modal tersebut yang biasanya terjadi antaragen. Misalnya, pengarang yang memiliki modal simbolis yang lebih dapat digunakan untuk memberi review atau kata pengantar terhadap pengarang muda, sehingga pengarang muda dapat mencapai posisi tertentu dalam arena sastra.

Sebagaimana yang telah disebutkan sebelumnya, dalam arena sastra terjadi pergulatan. Pergulatan tersebut ditujukan untuk mentransformasikan atau mempertahankan relasi kekuasaan yang telah dimiliki. Dalam hal ini, modal yang dimiliki oleh agen menjadi unsur yang penting dalam perebutan dan mempertahankan posisi yang dimaksud.

Melalui konsep habitus dan arena yang dikemukakan oleh Bourdieu, dapat ditelusuri apa yang membuat seseorang menjadi sastrawan yang diakui. Selain itu, 
konsep-konsep tersebut membawa pada cara menganalisis karya kultural yang membawa pada individu atau kelompok yang memproduksi karya tersebut. Mengenai hal ini, Bourdieu menyebutkan bahwa karya disituasikan sebagai ruang kemungkinan dalam pengambilan posisi yang didasarkan pada 'ruang' di mana suatu karya disituasikan, serta 'ruang' di mana kegiatan kultural pengarang berlangsung (Bourdieu, 2010).

Selain itu, di dalam arena sastra terjadi pergulatan, di dalamnya berlangsung perjuangan dan strategi, serta senjata ampuhnya ialah habitus dan modal (Harker, Mahar and Wilkes, 1990). Pergulatan tersebut termasuk praktik sebagai bentuk interaksi antara habitus dan arena. Kemudian, modal memberi para individu serta kelompok identitas untuk dikenal dan diakui. Perspektif dengan berbagai konsep ini kemudian digunakan untuk menganalisis objek material yang dipilih, yaitu mengenai posisi dan pencapaian Wisran Hadi dalam arena sastra Indonesia.

\section{METODE PENELITIAN}

Bourdieu menggunakan metode analisis yang ia gunakan dalam analisisnya terhadap arena sastra di zaman Flaubert. Metode ini didasarkan pada tiga unsur yang terikat atau berkaitan satu sama lain (Bourdieu, 2010: 257-258). Pertama, analisis tentang posisi yang ditempati arena sastra di dalam arena kekuasaan dan evolusinya sepanjang waktu. Kedua, struktur arena sastra. Struktur tersebut mencakup hubunganhubungan objektif di antara posisi-posisi yang dihuni para seniman atau kelompok yang bersaing untuk memperoleh legitimasi sastra. Ketiga, asal-usul habitus produsen yang berbeda-beda. Mengenai hal itu, praktik dalam arena sastra dianalisis melalui habitus yang terbentuk.

Berdasarkan metode tersebut, dilakukan elaborasi serta analisis asal-usul terkait pengarang serta berbagai struktur dan kelompok sosial, dalam hal ini ialah Wisran Hadi dalam arena sastra sebagai objek penelitian. Selain itu, data diperoleh melalui studi kepustakaan seperti tulisantulisan, baik tulisan ilmiah maupun artikel yang berkaitan dengan objek penelitian.

\section{PEMBAHASAN}

Wisran Hadi lahir di Lapai, Padang, Sumatra Barat pada tanggal 27 Juli 1945. Ia tumbuh dalam lingkungan keluarga penganut Islam yang taat. Ia merupakan anak keempat dari tiga belas bersaudara. Dari ketiga belas bersaudara tersebut, hanya Wisran Hadi yang aktif dalam bidang kesenian. Ayahnya bernama $\mathrm{H}$. Darwas Idris dan merupakan salah satu ahli tafsir terkemuka di Indonesia (alumnus Darul Hadist di Mekkah), serta juga seorang imam besar di masjid Muhammadiyah Padang. Selain itu, ayahnya juga merupakan seorang guru Pendidikan Guru Agama (PGA) serta dosen di Universitas Muhammadiyah Padang. Ibunya bernama Rafiah Syafei dan merupakan seorang guru Sekolah Dasar di Kandis Nanggalo. Masa kecil Wisran Hadi dominan dipengaruhi oleh kesenian tradisional Minangkabau, di antaranya ialah pertunjukkan randai dan kaba (Sofia, 2010; Wisran Hadi (19452011), n.d.).

Ketertarikan Wisran Hadi terhadap bidang kesenian telah muncul sejak ia berusia sepuluh tahun. Melalui wawancara 
dengan Sofia, ia mengatakan bahwa minat seni yang dimiliki berasal dari kecenderungan ibunya yang suka mengajarkan anak-anaknya bernyanyi sebelum tidur. Nyanyian tersebut di antaranya berupa Salawat Nabi dan kasidah (Sofia, 2010). Saat di Sekolah Dasar, Wisran Hadi menemukan buku Hikayat Hang Tuah di bawah tempat tidur ibunya yang kemudian ia baca secara diam-diam. Buku berbahasa Melayu tersebut susah untuk dipahami oleh Wisran Hadi, akan tetapi ia tetap membacanya dan hal itulah yang mengawali ketertarikannya terhadap bidang sastra.

Pada kenyataannya, memang dominan sastrawan-sastrawan atau seniman-seniman yang diakui dalam arena sastra dan seni, atau menjadi avand-garde di bidangnya, diawali dari perkenalan dengan hal-hal terkait sejak ia kecil. Misalnya, memiliki kebiasaan membaca dan dekat atau besar dalam lingkungan kesenian. Akan tetapi, juga tidak dapat dipungkiri bahwa tidak semua pengalaman tersebut yang mengantarkan seseorang menjadi sastrawan dan seniman. Di samping itu, ada pula sastrawan dan seniman yang memang tidak bertumbuh (ketika kecil) dalam lingkungan seperti demikian. Akan tetapi, kegigihan dalam mencapai hal yang diminati tetap dapat membuka peluang untuk mencapai posisi tersebut. Sebuah pencapaian berdasarkan perspektif Bourdieu bergantung pada habitus, arena yang ditempati, modal yang dimiliki, serta praktik dan strategi yang dilakukan. Berikut ialah penjabaran mengenai posisi dan struktur arena sastra yang ditempati oleh Wisran Hadi dalam arena kekuasaan; posisi dan pencapainnya dalam arena sastra; serta strategi yang dilakukan untuk mempertahankan posisi dalam arena tersebut.

\section{Posisi dan Struktur Arena Sastra dalam Arena Kekuasaan}

Arena sastra diposisikan sebagai arena yang otonom oleh Bourdieu. Akan tetapi, di sisi lain ia juga menyatakan kemustahilan untuk membuat tatanan kultural menjadi ranah otonom dan berkembang dengan aturan-aturannya sendiri (Bourdieu, 2010). Mengenai hal ini dapat diartikan bahwa posisi arena sastra memiliki otonomi yang relatif di dalam arena kekuasaan. Oleh sebab itu, arena sastra yang dibicarakan perlu untuk ditelusuri keberadaannya terkait dengan arena kekuasaan.

Posisi arena sastra terhadap arena kekuasaan disebut oleh Bourdieu menempati hierarki ganda. Hierarki pertama ialah prinsip hierarki heteronom yang meliputi kekuasaan, dan yang kedua ialah prinsip hierarki otonom yang meliputi prestise kesusastraan (Bourdieu, 2010). Prinsip hierarki heteronom dapat diukur berdasarkan indeks penjualan buku, jumlah pementasan, dan penghargaan. Mengenai hal ini, apabila suatu arena sastra yang ditempati oleh pengarang kehilangan otonominya, maka ia bukan lagi sebuah arena dan pengarang akan tunduk terhadap hukum dan aturan di arena kekuasaan, misalnya untuk kepentingan politik dan ekonomi.

Hierarki yang kedua ialah prinsip hierarki otonom. Bagian ini meliputi pengakuan atau memperoleh legitimasi. Hierarki ini dapat berujung pada kekuasaan tanpa perlawanan apabila 
bertujuan untuk memperoleh otonomi total. Prinsip ini dimaksudkan sebagai 'seni untuk seni'. Kemudian, arena produksi kultural pada bagian ini juga merupakan keterbalikan dari prinsip ekonomi. Seni untuk seni dapat pula mengarah pada artian bahwa keberhasilan artistik lebih diutamakan apabila dibandingkan dengan keberhasilan finansial. Hal tersebut menjadi lebih diutamakan karena pada dasarnya modal simbolis yang diperoleh serta dimikili dapat ditukar dengan modal ekonomi apabila telah mencapai keberhasilan artistik.

Terkait posisi arena sastra berdasarkan prinsip hierarki heteronom yang ditempati oleh Wisran Hadi, maka perlu pula ditelusuri tentang karya apa saja yang dihasilkan, pertunjukkan teater yang dipentaskan, hingga penghargaan yang diperoleh sebagai seorang pengarang atau seniman. Wisran Hadi mengawali kegiatan di bidang kesenian dimulai sejak ia kuliah jurusan seni rupa di Akademi Seni Rupa Indonesia (ASRI) Yogyakarta. Ketika masih berstatus sebagai mahasiswa, ia telah melakukan beberapa pameran lukisan. Berawal dari hal itu, kemudian ia mulai dikenal sebagai perupa atau pelukis meskipun masih berstatus sebagai mahasiswa (Syafril, 2017).

Selain melakukan pameran, Wisran Hadi juga berkegiatan dalam bidang kesenian lain. Di antaranya, ia bergabung dengan grup musik ikatan Minangkabau dan kegiatan teater (Sofia, 2010). Selama menjadi mahasiswa seni tersebut, ia tidak hanya aktif dengan kegiatan-kegiatan seni itu saja. Di sisi lain, ia juga menjadi anggota ikatan mahasiswa, bahkan menjadi ketua dalam organisasi Kesatuan Aksi Mahasiswa Indonesia (KAMMI), serta ketua di Himpunan Mahasiswa Islam (HMI) komisariat ASRI Yogyakarta. Keaktifan dan kontribusi Wisran Hadi terhadap organisasi kemahasiswaan Islam tersebut tentu saja dapat dikaitkan dengan bagaimana lingkungan tempat ia bertumbuh, atau bagaimana habitus yang ia tempati.

Meskipun lahir dalam keluarga penganut Islam yang taat, serta memiliki seorang ayah yang merupakan salah satu ulama besar di Sumatra Barat, akan tetapi ayahnya merupakan seseorang yang demokratis. Wisran Hadi kecil beserta saudara-saudaranya yang lain dibebaskan untuk membaca buku apa saja, meski buku kiri sekalipun. Selain itu, orang tuanya juga selalu memberikan arahan dan motivasi agar memiliki semangat, rasa ingin tahu, dan etos kerja yang tinggi. Berhubungan dengan persoalan bacaan, ia juga diperkenalkan dengan bacaan-bacaan seni dan karya-karya seniman yang telah mendunia (Syafril, 2017). Besar dan bertumbuh dalam didikan dan lingkungan seperti demikian, memberi pengaruh besar terhadap bakat dan pola pikirnya. Hal itu terlihat dari bagaimana ia memiliki banyak kegiatan ketika menjadi mahasiswa seni. Ia tidak hanya fokus pada satu bidang kesenian, akan tetapi aktif dalam beragam genre lain seperti musik dan teater.

Pada tahun 1967, setelah menamatkan pendidikan strata satu, Wisran Hadi kembali ke Padang. Akan tetapi, di kampung halaman ia dihadapkan pada kesulitan untuk meneruskan dan mengembangkan kegiatannya dalam bidang seni lukis. Pada waktu itu ia 
mengalami kesulitan untuk memperoleh bahan dan peralatan yang digunakan untuk melukis. Karena terkendala oleh hal tersebut, Wisran Hadi mengalihkan fokus keseniannya pada bidang teater (Syafril, 2017).

Selain menekuni bidang teater, Wisran Hadi juga bekerja sebagai guru di Sekolah Seni Rupa Indonesia (SSRI) Padang pada tahun 1971. Naskah teater pertamanya ditulis di tahun yang sama dengan judul "Dua Buah Segi Tiga". Naskah tersebut kemudian di pentaskan di SSRI (Sofia, 2010; Syafril, 2017). Ketekunan di bidang teater terus berlanjut pada tahun-tahun berikutnya hingga pada tahun 1975 Wisran Hadi memperoleh penghargaan pertamanya sebagai pemenang Sayembara Penulisan Naskah Drama Indonesia yang diselenggarakan oleh Dewan Kesenian Jakarta (DKJ). Naskah yang memenangkan penghargaan tersebut berjudul "Gaung" dan untuk pertama kalinya pula dipentaskan di Taman Ismail Marzuki (TIM).

Berdasarkan penjabaran tersebut, posisi arena sastra yang ditempati oleh Wisran Hadi berdasarkan prinsip hierarki heteronom dapat dikatakan berdiri pada posisi yang otonom atau tidak kehilangan otonominya dalam arena kekuasaan. Hal itu didasarkan pada kegiatan kesenian yang dilakukan, karya-karya yang dilahirkan, serta pernghargaan yang diterima mengingat tahun-tahun berlangsungnya berbagai pencapaian awal tersebut ialah pada rezim Orde Baru yang otoriter dan sentralis. Penjelasan tersebut juga terkait dengan posisi arena sastra dalam tataran prinsip hierarki otonom. Prinsip kegiatan berkesenian Wisran Hadi dimaksudkan sebagai seni untuk seni. Hal itu dapat dilihat atas pilihannya untuk menekuni bidang teater (bidang kesenian lain) ketika terkendala dalam seni lukis. Apabila yang diutamakan ialah keberhasilan finansial, tentu banyak bidang lain yang lebih menjanjikan daripada bidang kesenian. Akan tetapi, produksi kultural yang diawali oleh Wisran Hadi ialah untuk mencapai keberhasilan nilai artistik. Proses pencapaian awal tersebut pada akhirnya dapat mempertukarkan modal simbolis yang diperoleh dengan modal ekonomi. Pertukaran modal tersebut ialah memperoleh kesempatan untuk menampilkan teater atas penghargaan yang diperoleh di TIM yang pada masa itu menjadi pusat atau sentral kegiatan berkesenian di Indonesia.

Posisi arena sastra sebagai arena produksi kultural dalam arena kekuasaan, terkait dengan persoalan bagaimana karya seni dipahami sebagai manifestasi dari arena secara keseluruhan. Arena sastra memang terdapat di dalam arena kekuasaan. Akan tetapi, sebagaimana yang telah disebut sebelumnya, ia menempati otonomi yang relatif. Kerelatifan ini oleh Bourdieu disebut sebagai: seperti apapun derajat independensinya, akan tetapi ia juga terpengaruh oleh hukum dan prinsip arena yang menanunginya, seperti halnya mendapat pengaruh terkait kebijakan ekonomi dan politis.

Selain prinsip hierarki ganda, produk (karya) yang dihasilkan dalam arena digolongkan ke dalam arena produksi terbatas dan arena produksi skala besar (Bourdieu, 2010). Di dalam arena produksi terbatas, karya-karya yang diproduksi ialah karya murni, abstrak, dan 
eksoterik. Artinya adalah karya yang dihasilkan mengutamakan kualitas estetis, bukan kuantitas tuntutan pasar. Hal itu berbeda dengan arena produksi skala besar yang memiliki kecenderungan mengikuti tuntutan pasar agar meraih keuntungan dan laba ekonomi yang tinggi.

Penjelasan tersebut, apabila merujuk pada posisi arena sastra dalam arena kekuasaan, maka dapat dikatakan bahwa arena produksi skala besar berada dalam posisi didominasi oleh arena kekuasaan. Karya-karya yang dihasilkan cenderung berupa karya populer sebagaimana selera pasar untuk meraih pencapaian modal ekonomi. Terkait dengan arena yang ditempati oleh Wisran Hadi, karya yang dihasilkan tidak merujuk pada produksi skala besar. Pencapaian dan modal yang hendak didapatkan ialah modal estetis dan lebih mengutamakan proses. Pencapaian modal tersebut pada akhirnya mengarahkan Wisran Hadi memperoleh eksistensi atau pengakuan sebagai seorang seniman atau dramawan. Oleh sebab itu, arena sastra yang ditempati dalam hal ini ialah arena dengan prinsip hierarki otonom serta arena produksi terbatas di dalam arena kekuasaan.

\section{Posisi, Praktik, dan Pencapaian Wisran Hadi dalam Arena Sastra}

Pada pembahasan sebelumnya, telah diuraikan mengenai posisi dan struktur arena sastra yang ditempati oleh Wisran Hadi dalam arena kekuasaan. Melalui posisi arena yang otonom serta dengan produksi skala terbatas tersebut, juga telah dijelaskan mengenai proses serta pencapaian awal Wisran Hadi di dalam arena yang bersangkutan. Akan tetapi, bagaimana kemudian posisi tersebut menjadi ajek, seperti apa praktik berkesenian yang dilakukan, serta pencapaian apa saja yang diperoleh? Pembahasan mengenai persoalanpersoalan tersebut tidak terlepas dari modal simbolis yang dimiliki dan bagaimana modal tersebut dipertukarkan. Kedua hal itu kemudian juga tidak terlepas dari bagaimana asal-ususl habitus serta praktik yang terjadi di dalam arena sastra.

Perolehan penghargaan dari DKJ, selain sebagai latar penting pencapaian posisi Wisran Hadi dalam arena sastra, hal itu juga menjadi momentum untuk membuktikan eksistensi seniman-seniman di Sumatra Barat pada tahun-tahun tersebut serta setelahnya. Penghargaan yang diperoleh menandakan bahwa mereka diperhitungkan dalam kesenian Indonesia, sehingga kemudian memperoleh modal dan posisi tertentu dalam arena produksi kultural.

Menyadari adanya potensi tersebut, serta mulainya memperoleh modal simbolis sebagai seorang seniman serta mampu bersaing dalam arena sastra Indonesia, Wisran Hadi bersama rekanrekannya mendirikan grup teater pada tahun 1976. Grup tersebut bernama Bumi Teater dan Wisran Hadi dengan latar belakang pendidikan, pekerjaan, pengalaman, dan pencapaiannya di bidang kesenian dipercaya untuk mengetuai sekaligus menjadi pengasuh dalam komunitas tersebut (Syafril, 2017).

Mengenai posisi seorang pengarang dalam arena sastra yang ditempati, Bourdieu mengatakan bahwa perlu untuk mengembangan kriteria sendiri untuk memperoleh pengakuan 
kultural (Bourdieu, 2010: 169). Pengakuan dapat berasal dari kelompok sesama atau dari kelompok yang berbeda. Agar pengakuan kultural tersebut dapat dicapai, maka diperlukan posisi tertentu dalam arena sastra. Di dalam arena, suatu struktur terbentuk dari hubungan interaksi dan hubungan kultural. Hubungan interaksi dapat berupa bentuk hubungan perlawanan, menolak keanggotaan, hingga menolak pengakuan. Akan tetapi, justru praktik seperti itulah yang menyatukan keduanya dalam struktur arena.

Lebih lanjut, penyataan tersebut dapat diartikan bahwa pengakuan atau posisi dalam arena sastra dapat dicapai apabila praktik yang dilakukan menghasilkan efek tertentu di dalam arena. Pengakuan dan posisi sebagai seorang pengarang atau seniman tidak hanya dapat diperoleh melalui pemberian apresiasi, pujian, atau sanjungan. Akan tetapi, pengakuan tersebut juga dapat diperoleh berdasarkan kritikan, sanggahan, atau polemik yang pada awalnya ditujukan untuk menghalangi pemberian atau perolehan pengakuan.

Praktik berkesenian yang dilakukan oleh Wisran Hadi bersama Bumi Teater memang dapat dikatakan mencapai posisi legitimasi tertentu. Hal ini dapat disimpulkan berdasarkan penghargaan yang ia peroleh di tahuntahun pertama bersama Bumi Teater, yaitu antara tahun 1976 hingga 1996. Hampir berturut-turut di antara tahun tersebut ia menjadi pemenang dalam Sayembara Penulisan Sandiwara Indonesia yang diadakan oleh DKJ. Setidaknya, sebagaimana yang disebutkan oleh Sahrul bahwa dua belas naskah drama Wisran Hadi telah memenangkan beragam sayembara serta penghargaan lainnya (Sahrul \& Azwar, 2005). Penghargaan tersebut belum termasuk penghargaan yang diperoleh terhadap karya-karya genre lain seperti novel dan cerpen.

Pencapaian yang diperoleh tersebut didasarkan pada ciri khas naskah serta pertunjukan teater yang disutradarai oleh Wisran Hadi. Ia mengeksplorasi bahasa dan kata sedemikian rupa dalam karya-karyanya. Hal itu merupakan bentuk penerapan konsep keindahan dari Minangkabau. Anwar misalnya mengatakan bahwa konsep keindahan dikenal oleh orang Minangkabau terutama ialah melalui keindahan bahasa (Anwar, 1976). Keindahan bahasa tersebut dapat dilihat dari pepatah dan petitih yang khas dari Minangkabau, atau apa yang disebut oleh A.A. Navis sebagai kato kieh (Navis, 1984).

Di satu sisi, eksplorasi kata dan bahasa dalam praktik berkesenian yang dilakukan oleh Wisran Hadi dapat dikatakan sebagai cerminan konsep keindahan tersebut. Akan tetapi, di sisi lain, juga dapat dinilai sebagai 'ruang kemungkinan' yang merujuk pada bentuk perlawanan terhadap kedominanan naskah-naskah yang ditulis oleh pengarang lain. Misalnya, A. Teew menyatakan bahwa pada tahun 1970-an terbentuk batas antara kebudayaan nasional dengan kebudayaan daerah yang berakar dari sikap para budayawan yang berorientasi ke Barat atau kemodernan (Rendra, 1996). Selain itu, bentuk pemerintahan rezim Orde Baru yang sentralis juga bukan tidak mungkin memberikan pengaruh yang signifikan. Menyadari adanya ruang kemungkinan tersebut, mengantarkan Wisran Hadi 
untuk mengemukakan ciri khas drama dengan nuansa lokal yang kental. Junus misalnya juga mengatakan bahwa dalam drama-drama yang ditulis oleh Wisran Hadi, terdapat upaya demitefikasi berdasarkan cerita dan tokoh-tokoh yang terdapat dalam kaba dan tambo, hingga tokoh sejarah Perang Padri seperti Tuanku Imam Bonjol (Birowo, 2014).

Ruang kemungkinan yang dieksplor oleh Wisran Hadi melalui karyakaryanya, meskipun memperoleh berbagai penghargaan, akan tetapi beberapa di antaranya juga menyebabkan berbagai kontroversi. Hal itu dikarenakan naskah dan pementasan Wisran Hadi bersama Bumi Teater dianggap mengusik serta merusak marwah alam pikiran kaum tradisional di Minangkabau (Ramadhani, 2018). Misalnya, melalui naskah "Malin Kundang”, sosok legenda tersebut oleh Wisran Hadi justru dihadirkan bukan sebagai anak yang durhaka. Hal ini oleh para tradisionalis dinilai merusak mistikisme atau legenda yang telah menjadi salah satu ciri khas di Minangkabau. Pementasan yang dianggap kontroversi lainnya ialah terkait dengan tokoh Imam Bonjol. Kepahlawanan Imam Bonjol justru ditampilkan sebagai sosok yang memiliki rasa takut dan keraguraguan. Penjungkirbalikan penggambaran tokoh tersebut mendapat kecaman dan pelarangan dari pejabat Sumatra Barat terhadap kelompok Bumi Teater ketika mereka hendak menggelar pertunjukkan di TIM pada tahun 1997 (Febrianti, 2018).

Beragam pengakuan, praktik, serta pencapaian yang dijabarkan pada paragraf-paragraf sebelumnya dapat dinyatakan sebagai proses legitimasi posisi Wisran Hadi di dalam arena sastra.
Posisi dominan yang ia tempati_terutama dalam arena sastra Sumatra Barat_dikarenakan habitus yang dilalui, praktik-praktik berkesenian yang dilakukan, perolehan serta pertukaran modal simbolis, hingga pencapaian atau penghargaan yang didapatkan. Posisi tersebut juga dapat dilihat berdasarkan legitimasi atas karya-karya yang ditulis, penyutradaraan pertunjukkan dengan mengeksplorasi kata dan bahasa yang khas, serta kebertahanan kelompok yang dimiliki, yakni Bumi Teater.

\section{Strategi Wisran Hadi dalam Mempertahankan Posisi di Arena Sastra}

Posisi Wisran Hadi dapat dikatakan mendominasi, terutama dalam bidang teater di Sumatra Barat. Posisi tersebut menjadi ajek berdasarkan beberapa hal. Di antaranya, posisi yang dicapai terkait dengan kanonisasi yang diperoleh melalui karya-karya yang dimenangkan dalam Sayembara Penulisan Sandiwara yang diselenggarakan oleh DKJ.

Selain itu, habitus Wisran Hadi juga menunjukkan atau mengarah pada kedominanan untuk mengeksplorasi serta mengelaborasi kata kias dan idiom-idiom tradisional Minangkabau dalam karyakaryanya. Hal ini sesuai dengan artian habitus itu sendiri yang terkait dengan pengalaman dan pengajaran yang dilalui secara eksplisit (Jenkins, 2004). Pengalaman dan pengajaran tersebut kemudian saling memengaruhi dan melebur (Fashri, 2007). Sebagaimana yang telah diuraikan pada pembahasan sebelumnya, Wisran Hadi terbiasa membaca buku dari beragam genre. Habit 
tersebut kemudian dapat dilihat dari wujud karya yang ia hasilkan.

Eksplorasi kata dan bahasa yang ditampilkan oleh Wisran Hadi dalam karyanya tidak hanya dielaborasi dalam naskah-naskah drama yang ia tulis, akan tetapi juga dalam karya sastra lain seperti novel dan cerpen. Misalnya, dalam novel Persiden (2012), ia juga melakukan hal yang dapat dikatakan mirip. Ia mengeksplorasi sedemikian rupa kata-kata sehingga menghadirkan narasi deskriptif yang sangat jelas. Pepatah-pepitih dan idiom-idiom yang menjadi ciri khas dalam bahasa Minangkabau tidak jarang ia preteli sedemikian rupa. Selain itu, namanama tokoh yang dihadirkan dalam karya juga memiliki makna tertentu dalam bahasa Minangkabau.

Selain melalui karya-karya yang dihasilkan, strategi pencapaian posisi hingga menjadi ajek- yang dicapai oleh Wisran Hadi juga terkait dengan keberadaan kelompok Bumi Teater. Birowo di antaranya mengatakan bahwa beberapa kritikus seperti Ivan Adilla, Mursal Esten, Umar Junus, dan Darman Moenir turut melegitimasi Bumi Teater sebagai contoh dan ukuran kelompok sastra sebagaimana seharusnya (Birowo, 2014). Hal itu semakin mengukuhkan posisi dan dominasi Bumi Teater, terutama dalam ruang lingkup arena sastra di Sumatra Barat hingga dekade 1990-an.

Eksplorasi bahasa dan kata sedemikian rupa merupakan salah satu strategi bagi Wisran Hadi dalam praktik berkesenian. Hal itu pada akhirnya menjadi ciri khas yang melekat dalam karyanya. Hal lain yang dapat digolongkan sebagai strategi ialah bagaimana ia memosisikan karya-karya tersebut. Dengan kata lain, terdapat hubungan antara 'ruang' di mana suatu karya disituasikan, dan 'ruang' pengarang di mana suatu kegiatan kultural berlangsung (Bourdieu, 2010). Karyakarya yang dihasilkan misalnya disituasikan sebagai ruang pengambilan posisi dalam arena yang ditempati.

Sebagaimana yang telah dibahas sebelumnya, terdapat kecenderungan bagi Wisran hadi untuk mengeksplorasi kata dan bahasa dalam karya-karyanya sedemikian rupa. Selain itu, juga terdapat kecenderungan mengisahkan hal-hal yang bersifat kental dengan kedaerahan, sejarah, hingga religiositas. Kecenderungan tersebut terkait dengan ruang posisi Wisran Hadi yang lahir serta besar dalam lokalitas Minangkabau. Selain itu, ia juga bertumbuh dalam keluarga yang religius, intelektual, serta demokratis.

Ruang posisi tersebut kemudian berhubungan dengan bagaimana karyanya disituasikan. Terdapat ruang kemungkinan yang memberi peluang bagi Wisran Hadi untuk mencapai posisi dengan mengelaborasi hal-hal yang dekat dengan dirinya dalam berkarya. Kemungkinan tersebut kemudian dijadikan sebagai strategi dalam pencapaian posisi dalam arena sastra.

Mengeksplorasi kata, mempreteli legenda serta sejarah, mengelaborasi kembali mengenai kaba dan tambo menjadi keabsahan tersendiri bagi Wisran Hadi untuk memperoleh legitimasi dalam arena sastra. Strategi tersebut kemudian berujung pada pengakuan sebagai seorang dramawan, novelis, penyair, dan bahkan juga cerpenis. Selain itu, ruang di mana karya disituasikan dalam ruang kegiatan 
kultural memperoleh beragam penghargaan. Karya disituasikan berdasarkan gagasan pengarang yang meliputi unsur historis, habitus, struktur arena yang ditempati, posisi di dalam arena yang bersangkutan, hingga situasi dan kondisi realitas sosial yang menjadi sumber sekaligus sasaran dari karya yang dihasilkan.

\section{PENUTUP}

Berdasarkan

penjabaran

pembahasan pada beberapa subjudul sebelumnya, dapat disimpulkan bahwa Wisran Hadi merupakan sastrawan yang menghasilkan karya sastra dengan berbagai jenis genre sastra seperti naskah drama, novel, cerpen dan puisi. Hal itu membawanya pada pemerolehan pengakuan sebagai seorang dramawan, novelis, penyair, cerpenis, dan bahkan juga pelukis. Posisi dominan yang ditempati oleh Wisran Hadi dalam arena sastra didasarkan pada beberapa hal, di antaranya habitus yang dilalui, praktikpraktik berkesenian yang dilakukan, perolehan serta pertukaran modal simbolis, hingga pencapaian atau penghargaan yang didapatkan. Pencapaian posisi juga berhubungan dengan legitimasi atas karya-karya yang ditulis (baik yang memperoleh penghargaan hingga yang menimbulkan kontroversi), penyutradaraan pertunjukkan dengan mengeksplorasi kata dan bahasa yang khas, serta kebertahanan kelompok yang dimiliki, yakni Bumi Teater.

Keajekan posisi Wisran Hadi dalam arena sastra didasarkan pada praktik dan strategi-strategi yang dilakukan. Praktik dan strategi tersebut meliputi: (1) menghasilkan karya dalam beragam genre (naskah drama, pertunjukkan teater, novel, cerpen, hingga seni lukis); (2) memiliki ciri khas dengan ekplorasi kata dan bahasa serta mempreteli kisah-kisah klasik (kaba dan tambo), serta sejarah; dan (3) karya yang disituasikan berdasarkan beragam unsur, seperti habitus, struktur arena yang ditempati, posisi dalam arena, hingga situasi dan kondisi realitas sosial yang menjadi sumber serta sasaran tempat karya-karya tersebut dihadirkan.

\section{DAFTAR PUSTAKA}

Afrianda, P. D., \& Samsiarni. (2018). "Kaitan Makna Kontekstual dengan Budaya Minangkabau dalam Novel Persiden Karya Wisran Hadi." Jurnal Bahasa Lingua Scientia, 10(2), 287300.

Aisyah, N. (2020). "Perubahan Budaya Minangkabau Pada Novel Persiden Karya Wisran Hadi Perspektif Adat Basandi Syarak, Syarak Basandi Kitabullah." Universitas Muhammadiyah Malang.

Anggraini, N. (2015). "Pergeseran Nilai Budaya Minangkabau Dalam Novel Dari Surau Ke Gereja Karya Helmidjas Hendra Dan Novel Persiden Karya Wisran Hadi (Tinjauan Sastra Banding)." Jurnal Dinamika UMT, 1(1), 63-70.

Anwar, K. (1976). "Minangkabau, Background of the Main Pioneers of Modern Standard Malay in Indonesia." Archipel, 12(1), 77-93.

Birowo, P. (2014). "Teater 'Tanpa-Kata' dan 'Minim-Kata' di Kota Padang Dekade 90-an dalam Tinjauan Sosiologi Seni." Ekspresi Seni: Jurnal Ilmu Pengetahuan Dan Karya Seni, 16(2), 314-335. 
Bourdieu, P. (1990). The Logic of Practice. Translated by Richard Nice. Stanford: Stanford university press.

Bourdieu, P. (2016). Arena Produksi Kultural: Sebuah Kajian Sosiologi Budaya. Terjemahan oleh Yudi Santosa. Yogyakarta: Kreasi Wacana. Kreasi Wacana.

Bourdieu, P. (2011). Choses Dites: Uraian dan Pemikiran. Terjemahan oleh Ninik Rochani Sjams. Yogyakarta: Kreasi Wacana. Kreasi Wacana.

Fashri, F. (2007). Penyingkapan Kuasa Simbol: Apropriasi Reflektif Pemikiran Pierre Bourdieu. Yogyakarta: Juxtapose.

Fatimah, S. (2008). "Mencermati Perubahan Sosial Masyarakat Minangkabau melalui Novel Tamu karya Wisran Hadi." Jurnal Humaniora, 20(3), 278-285.

Febrianti. (2018). "Cerita Tiga Putra Mahkota." Koran.Tempo.Co.

Harker, R., Mahar, C., \& Wilkes, C. (1990). (Habitus x Modal) + Ranah = Praktik. Terjemahan oleh Pipit Maizer. Yogyakarta: Jalasutra.

Jenkins, R. (2004). Membaca Pikiran Pierre Bourdieu. Terjemahan oleh Nurhadi. Yogyakarta: Kreasi Wacana.

Navis, A.A. (2018). Jodoh. Jakarta: Grasindo.

Navis, Ali Akbar. (2015). Alam Terkembang Jadi Guru: Adat dan Kebudayaan Minangkabau. Padang: PT Grafika Jaya Sumbar.
Novelly, Y. A., Samsiarni, S., \& Septia, E. (2020). "Persoalan Identitas Sosial Tokoh Laki-laki dalam Novel Persiden Karya Wisran Hadi." Magistra Andalusia: Jurnal Ilmu Sastra, 2(2).

Prasasti, B. W. D., \& Anggraini, P. (2020). "Nilai-nilai Budaya Minangkabau dalam Naskah Drama Dr. Anda Karya Wisran Hadi." Fon: Jurnal Pendidikan Bahasa Dan Sastra Indonesia, 16(2), 79-88.

Putri, D. (2016). "The Shift of Minangkabau Cultural Values in the Novel Persiden by Wisran Hadi (a Genetic Structuralism Approach)." Humanus: Jurnal Ilmiah Ilmu-Ilmu Humaniora, 15(2), 120-130.

Ramadhani. (2018). "Wisran Hadi, Tetaer, dan Hidupnya." Klikpositif.Com.

Rendra, W. S. (1996). Potret Pembangunan dalam Puisi. Bandung: Pustaka Jaya.

Sahrul, N. (2005). Kontroversial Imam Bonjol. Padang: Penerbit Garak.

Sofia, M. (2010). "Wisran Hadi: Biografi Seorang Sastrawan 1972-2010." Padang: Universitas Andalas.

Sugiarti. (2013). "Representasi Identitas dan Etnisitas Minang dalam Novel Persiden Karya Wisran Hadi." Jentera, 2, 26-38.

Sugiarti, S., \& Putra, C. R. W. (2019). "Representation of Culture Ecology in Wisran Hadi's Persiden, Generasi Ketujuh." Litera, 18(1), 17-35.

Syafril. (2017). Kajian Budaya: Tetaer Postmodern Indonesia. Padang: Penerbit Erka. 
Wisran Hadi (1945-2011). (n.d.). Zarman, R. (2014). "Pengaruh dan Ensiklopedia Sastra Indonesia. Dampak Standarisasi Orde Baru Retrieved November 3, 2020, from dalam Arena Sastra Di Sumatra Barat http://ensiklopedia.kemdikbud.go.id/ sastra/artikel/Wisran_Hadi Di Era Reformasi." Turast: Jurnal Penelitian \& Pengabdian, 2, 203210. 